Article

\title{
Why Do Koreans Love Ethnic Players in the MLB? A Focus on Ethnic Identity and Player Identification
}

\author{
Jong-Woo Jun ${ }^{1}$, Jun-Hyuk Cho ${ }^{1}$ and Ji-Hoon Lee ${ }^{2, *}$ \\ 1 School of Communications, Dankook University, Yongin-si 16890, Korea; jwjun@dankook.ac.kr (J.-W.J.); \\ cyberpd2@gmail.com (J.-H.C.) \\ 2 Department of Communication, Underwood International College, Yonsei University, Seoul 03722, Korea \\ * Correspondence: melofrenzy@gmail.com
}

Citation: Jun, J.-W.; Cho, J.-H.; Lee, J.-H. Why Do Koreans Love Ethnic Players in the MLB? A Focus on Ethnic Identity and Player Identification. Sustainability 2021, 13, 12955. https://doi.org/10.3390/ su132312955

Academic Editors: Iris Vermeir and Alexandre Garcia-Mas

Received: 25 August 2021

Accepted: 12 November 2021

Published: 23 November 2021

Publisher's Note: MDPI stays neutral with regard to jurisdictional claims in published maps and institutional affiliations.

Copyright: (c) 2021 by the authors. Licensee MDPI, Basel, Switzerland. This article is an open access article distributed under the terms and conditions of the Creative Commons Attribution (CC BY) license (https:// creativecommons.org/licenses/by/ $4.0 /)$.

\begin{abstract}
Asians hold a collectivistic culture, and they feel attachment to people who have the same ethnic background. This study explored how roles of ethnic identity influenced fan behaviors of Korean audiences toward Hyun-jin Ryu, the Korean Major League Baseball player. The results showed that ethnic identity influenced player identification, which led to attitudes toward the L.A. Dodgers. Congruence mediated the relationship between ethnic identity and player identification. It is also found that transportation mediated the relationship between player identification and attitudes toward the L.A. Dodgers. These results provide a cultural explanation of fan behaviors of ethnic players. Managerial implications can also be found.
\end{abstract}

Keywords: ethnic identity; player identification; congruence; transportation; L.A. Dodgers

\section{Introduction}

Major League Baseball (MLB for short) is one of the most popular professional sports leagues with a massive fandom worldwide. Fans of MLB are not just limited to the United States, as more sport games have become valuable contents for television business and makes enormous profit from all over the world. The broadcasting rights of MLB games are exported to other countries, and Korea is one of them. MBC Sport Plus, one of the main cable sport channel operators in Korea, has covered MLB games for many years-although Spotv has acquired the rights and is the new provider for the 2021 season-attracting a tremendous number of Korean baseball fans. It is now very common to see foreign players from all over the world in MLB, and among them are Asian players mostly from Japan, Taiwan, and Korea. Hyun-jin Ryu, a Korean pitcher, has become one of the famous MLB players rather recently. While playing for the Los Angeles Dodgers between 2013 and 2019, he became one of the most dominant pitchers in the game, and he is still one of the most proficient and capable players after having signed a new, four-year deal with the Toronto Blue Jays, starting in 2020.

The history of Korean players in MLB dates back to 1994 when Chan Ho Park made his pitching debut with the L.A. Dodgers, and since then, more than 20 Korean athletes have played in MLB, making Korea one of the biggest and valuable markets for the league. Chan Ho Park truly ushered in a new era for MLB, as more and more Korean players succeeded in signing with a number of MLB teams over the years. Some of the biggest names who have played in MLB includes Byung Hyun Kim (Arizona Diamondbacks and Boston Red Sox), Sinsoo Choo (Cleveland Indians and Texas Rangers), and Hee Seop Choi (Chicago Cubs and L.A. Dodgers), in addition to the aforementiond Chan Ho Park and Hyun-jin Ryu [1].

It is only natural that Koreans love sports players with their ethnic background, especially with the extended coverage of MLB games on cable television in Korea. Two or three full MLB games are aired on Korean cable television on a daily basis, mostly showing the games featuring Korean players such as Hyun-jin Ryu and Jiman Choi. Even though 
Korean MLB fans support the league in general, even rooting for a variety of teams without Korean players (such as universally popular team franchises such as the New York Yankees and Boston Red Sox), they mainly identify with and strike a chord with ethnic players. This can be explained by ethnic identity based on the social identity theory.

This study is designed to explore the roles of ethnic identity on player identification and even team identification. The originality of this study is to explore effects of cultural orientation on their ethnic sport player. The proposition is that Asians' value of ethnic identity might influence consumers' perception, attitudes, and behaviors. The relationship between Hyun-jin Ryu and L.A. Dodgers is the focus of this research. Player identification was used as a major mediator, and congruence and transportation are used as additional mediators in the research model (Figure 1).

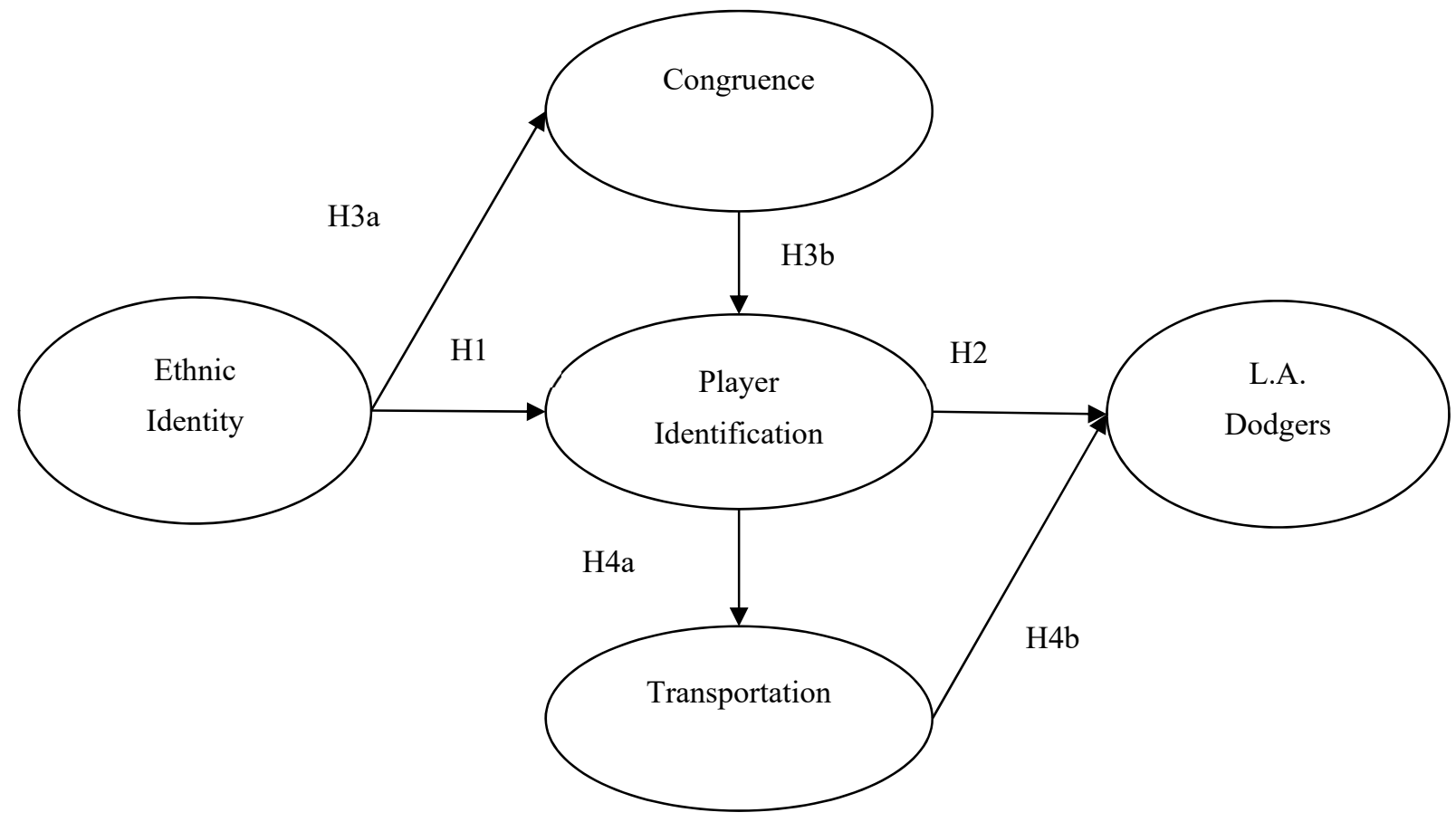

Figure 1. Research model.

\section{Literature Review}

\subsection{Social Identity Theory}

Social identity theory classifies groups into in-group and out-group. They feel attachment to in-groups even though groups are divided simply based on colors of their clothes [2]. People use group identity to improve self-esteem when they win, and to protect self-image when they lose. When they win, they use the word, "we", and connect themselves to the win. This is called BIRGing (basking in reflected glory) [3]. However, when they do not receive good evaluation, they put psychological distance from the group, and try to deny the connection with the group. This is called CORFing (cutting off reflected failure) [4]. Grouping is essential to perform efficient social functions [5].

Social identity includes roles, tasks, and membership with groups such as social groups or cultural heritage. This may include an ethnic group or an identity for an organization to which one belongs [6]. In-group favoritism can be found in sports teams or players. Team identification is very important because it plays significant roles on sports fan behaviors [7]. Accordingly, the concept of identification is frequently adapted to sport players.

Social identity consists of two concepts: ethnic identity and acculturation. Acculturation refers to the migrants' adaptation to the culture of residence that is distinct from their own culture [8]. In contrast, ethnic identity refers to "people's perception of themselves as members of a community because of their common culture, ancestry, language, history, religion and customs" [9]. 


\subsubsection{Ethnic Identity}

Ethnic identity can be defined as "the extent to which individuals affiliate with their original culture and adhere to its traditional values" [10]. Ethnic identity has been defined in various ways. Tajfel (1981) defined ethnic identity as "that part of an individual's selfconcept which derives from knowledge of membership of a social group together with the value and emotional significance attached to that membership" [11]. Phinney (1994) suggested that ethnic identity is composed of "a feeling of belonging to one's group, a clear understanding of the meaning of one's membership, positive attitudes towards the group, familiarity with its history and culture, and involvement in its practices" [12,13]. Ethnic identity also "refers to a self-view that deals with a shared sense of identity with others who belong to the same group" [14]. In specific ethnic group studies, for example, Germany is the most generous of those who seek asylum or refuge from Eastern Europe. The ethnic identity of the German was formed throughout history by inclusion and exclusion from other cultures [15].

Koreans show unique ethnic identity. It might stem from cultural values that Koreans hold. A representative example of Korean cultural identity is community spirit, which prioritizes community interests rather than individual needs [16]. In 2012, the Korean Studies Advancement Center discovered "fermentation/well pickled, affection, naturalness, community, beseemingness, humor, pleasure, politeness, dynamics, and patience" as the top 10 cultural genes of Koreans. As a representative cultural gene, the research result, 'natural beseemingness with the community' was derived. In a study of Koreans residing in the United States, the duration of residence in the United States had a negative effect on Korean cultural identity, English proficiency had a positive effect, and gender did not show any statistically significant results [17].

Ethnic identity influenced consumer behaviors in a variety of areas such as clothes, food, entertainment, and sports. In the study of product purchase, the composition of ethnic identity was positively associated with the purchase of ethnic products [18]. In addition, the ethnic identity of consumers has differently affected ethnic consumers' behavior according to product category. Similar to ethnic identity, there is a link between sports participation identity and positive adjustment [6].

\subsubsection{Player Identification}

Individuals who have ethnic subcultures relate themselves to sports or sports teams in order to increase their self-esteem or gain experience that is achieved through the success of others [19]. Identification research starts from organization identification research based on the theory of social identity. Identification is associated with a satisfactory self-definition relationship with another person or group, resulting in accepting actions derived from another person or group [20]. For example, fans who prefer professional basketball perceive the team they support as if they are part of the team, or if they perceive that they are part of the team, they are identified with the team and share their joy and sadness with the team [21].

Harrolle and Trail (2007) conducted a study evaluating the relationship between ethnic identity and sports fan behaviors among Latino immigrants [22]. As a result, ethnic identity was significantly related to specific sport identification. Ethnic identity had a significant impact on identification with ethnically special sports. It also derives that ethnic identity is an important variable in predicting consumption of a particular sport (soccer) that is related to the attributes of Italian Canadians [23]. The identification of a fan is a psychological connection or attachment to many sports-related subjects, such as players, teams, or specific sports [24]. Fan identification is one of the most significant variables in predicting sports consumption.

It is accepted that ethnic identity is a useful concept for understanding how motives, attitudes, and future behavioral intentions of individuals with different ethnic subcultures become sports fans [25]. Ethnic identity has a positive impact on the consumption of sports product in the home country $[23,26]$. According to the literature, player identification 
can be formed from various sources, and ethnic identity is one of the major elements affecting ethnic player identification [22]. Based on the role of ethnic identity in the sports environment, we propose the following hypothesis that ethnic identity affects identification with ethnic sports players:

Hypothesis 1 (H1). People who have strong ethnic identity will feel more ethnic player identification.

Consumers feel that they are identified with a brand that can reflect their self-concept and express their self. Existing research has shown that as brand identification increases, the relationship satisfaction with the brand increases and the brand loyalty directly affects the use intention, recommendation intention, and purchase intention increase [27]. If a consumer has an attachment to a sports star, it has been shown to affect the purchase and recommendation intention of the sports star's sponsored brand [28]. Among the attributes of professional sports teams, the star player factor influenced the team identification and subsequently influenced the corporate identification [21]. Sports players can increase their team's performance, spectators, viewership, and product sales to differentiate their team from other teams [29]. In studies related to the effects of sports players on their teams and sponsorships, users consuming sports identify themselves with sports teams, coaches, communities, sport types or sport levels, and sports players are one of the main factors in attracting sports teams [30]. Sports players influence their team's brand equity, including brand loyalty, awareness, perceived quality, and brand reputation. Star players influence fan loyalty and team awareness. They attract fans to the team and remain a loyal supporter of the team [31]. Star players help to increase the overall attractiveness of the team [32]. The fan's identification is mediated by ethnic identity and consumption behavior for sports related to a particular culture [26]. In this regard, it can be hypothesized that player identification affects attitudes towards the player's team. Furthermore, we can also hypothesize that player identification could mediate the relationship between ethnic identity and the belonging team:

Hypothesis 2 (H2). Player identification will positively influence attitudes toward the L.A. Dodgers.

\subsection{Congruence}

Congruence is a concept that describes a consumer's perception of similarity [33]. According to the matchup hypothesis, endorsement is more effective when fitting between an endorser and an endorsed product [34]. Congruence has been studied in various fields such as advertising, branding, sports marketing, and sponsorship. The advertising effectiveness of a famous advertising model is determined by the congruence of the famous model and the product [35]. The congruence effect can also be found in sponsorship areas. Sponsorship campaigns with high congruence between sponsors and events can better communicate product-related messages to sports-related consumers through a central path [36].

The degree of increase in image congruence due to brand sponsorship was moderated by the functional similarity between the sponsor brand and the sponsored sporting event [37]. When the self-image and the brand image match, it plays a positive role in the attitude toward the brand, and as a result, the purchase of the brand increases, resulting in the consumer becoming a loyal customer [27]. In the existing TV character study, identification occurred more easily when the TV viewer actually felt similar to the characters in the media [38]. Based on the above discussion, it can be assumed that identification is more likely if one thinks that a person with ethnic identity has similarities with the sports player. Furthermore, the relationship between ethnic identity and congruence is also proposed because congruence perceptions on the ethnic player stems from similar ethnic backgrounds: 
Hypothesis 3 (H3). Congruence will mediate the relationship between ethnic identity and player identification.

Hypothesis 3a (H3a). Ethnic identity will influence congruence.

Hypothesis $\mathbf{3 b} \mathbf{b} \mathbf{H} 3 \mathbf{b})$. Congruence will influence player identification.

\subsection{Transportation}

Transportation refers to the creation of a specific image as a response to the narrative as an emotional response [39], which means a mental shift to engage with the world of the story. Both transportation and identification are concepts that describe how the audience is engaged in the media. Identification means looking at the character positively and showing strong attachment to the character and transportation means that the level of absorption is strengthened [40]. Absorption into the story through transportation reduces cognitive resources and reduces the chance of negative reactions [41]. The experience of transportation leads to a positive evaluation of the claims or facts related to it. If the elaboration likelihood model explains the cognitive process in persuasion, transportation explains the persuasion process in the emotional dimension [41].

In health-related research, transportation through narratives serves to reduce controversy and increase acceptance and motivation for health information related to cancer [42]. A study on branded entertainment also showed that the level of transportation had a positive effect on both the content attitude and the brand attitude [43]. Among the European American, Mexican American, and African American women groups surveyed for cervical cancer, Mexican American women were the most transported and identified with the characters in Latin. Identification and transportation of specific characters influenced changes in knowledge and attitudes and behavioral intentions [44]. When exposed to modeled behavior and experiencing identification with a character in the narrative, self-efficacy increases and critical motivation for the program decreases, leading to changes in viewing behavior [45].

Transportation is a significant mediator of the influence of persuasion on attitudes [44]. People can be immersed in narratives as a result of identification with characters in the media, and such transportation can mediate the enjoyment of narratives [46]. A characteristic of the transportation process is that it is uncritically immersed in the narrative [47], which can be applied to the experience of identification with player. That is, if the transportation is experienced after identification with the sports player, it can be expected that the attitude toward sports player and his team will be positive:

Hypothesis 4 (H4). Transportation will mediate the relationship between player identification and the L.A. Dodgers.

Hypothesis 4a (H4a). Player identification will positively influence player identification.

Hypothesis $4 \mathbf{b} \mathbf{( H 4 b )}$. Transportation will positively influence attitudes toward the L.A. Dodgers.

\section{Methodology}

This used a survey research method. A professional research company was hired, and its panel was used. The survey was conducted from 26 to 31 December 2018.

\subsection{Samples}

A total of 7213 emails were sent, and 911 respondents participated in the survey. The response rate was $12.6 \%$. Of these, 242 were screened out because they did not watch any MLB games in 2018, 600 out of 911 samples finished the survey, and 49 gave up the survey. Among 600 respondents, 348 (58\%) were male and $252(42 \%)$ were female. Ages of respondents raged from 19 to 69 , and their mean age was $45.0(\mathrm{SD}=11.6)$ years (Table 1$)$. 
Table 1. Key statistics of dependent variables.

\begin{tabular}{|c|c|c|c|c|}
\hline Variables & Measurement and Dimensions & $\mathbf{M}$ & SD & CFA \\
\hline \multirow{7}{*}{$\begin{array}{l}\text { Ethnic } \\
\text { Identity }\end{array}$} & I'm very proud of my Korean ethnic background & 4.94 & 1.13 & 0.806 \\
\hline & I highly attached to Korean culture & 5.10 & 1.12 & 0.805 \\
\hline & I love Korean culture and tradition & 5.22 & 1.11 & 0.812 \\
\hline & I am influenced by Korean history, tradition, customs, and ethics & 5.21 & 1.08 & 0.744 \\
\hline & I feel strong ethnic identification & 5.07 & 1.14 & 0.834 \\
\hline & I think in Korean way in many aspects of my life & 5.09 & 1.10 & 0.710 \\
\hline & Index & 5.10 & 0.92 & $\alpha=0.91$ \\
\hline \multirow{4}{*}{ Congruence } & Ryu has similar images with me & 3.61 & 1.29 & 0.933 \\
\hline & Associated images of Ryu are related to me & 3.55 & 1.34 & 0.933 \\
\hline & Images of Ryu are not different from me & 3.65 & 1.36 & 0.860 \\
\hline & Index & 3.60 & 1.25 & $\alpha=0.93$ \\
\hline \multirow{7}{*}{$\begin{array}{c}\text { Player } \\
\text { Identification }\end{array}$} & When someone criticizes him, it feels like a personal insult. & 4.47 & 1.27 & 0.823 \\
\hline & I am very interested in what others think about him & 4.48 & 1.39 & 0.845 \\
\hline & When I talk about him I usually say 'we' rather than 'they'. & 4.07 & 1.44 & 0.867 \\
\hline & His successes are my successes. & 4.05 & 1.45 & 0.881 \\
\hline & When someone praises him, it feels like a personal compliment. & 3.94 & 1.46 & 0.890 \\
\hline & If a story in the media criticized him I would feel embarrassed. & 3.73 & 1.42 & 0.706 \\
\hline & Index & 4.12 & 1.22 & $\alpha=0.94$ \\
\hline \multirow{5}{*}{ Transportation } & I was immersed in the MLB & 4.18 & 1.31 & 0.911 \\
\hline & MLB games stimulated my emotions & 4.21 & 1.39 & 0.920 \\
\hline & When I watch MLG games, I can easily focus on it & 4.33 & 1.38 & 0.888 \\
\hline & I want to know the ending of this season of MLB & 4.56 & 1.32 & 0.809 \\
\hline & Index & 4.32 & 1.23 & $\alpha=0.93$ \\
\hline \multirow{5}{*}{ L.A. Dodgers } & Favorable & 4.84 & 1.13 & 0.873 \\
\hline & Positive & 4.82 & 1.20 & 0.880 \\
\hline & Good & 4.70 & 1.25 & 0.937 \\
\hline & Likable & 4.77 & 1.23 & 0.918 \\
\hline & Index & 4.78 & 1.12 & $\alpha=0.95$ \\
\hline
\end{tabular}

\subsection{Measurements}

Ethnic identity was defined as cultural orientation toward Korean identity and measured by the scales that Jun, Ham, and Park used [18]. Congruence was measured by the scales of Gwinner [48]. Player identification was measured using scales of Mael and Ashforth [49]. We measured transportation modifying the original scales of Green and Brock [41]. Attitudes toward the L.A. Dodgers were measured by four scales of Holbrook and Batra [50].

\section{Results}

\section{Hypotheses Testing}

This study used a statistical method of SEM (Structural Equation Modeling) to analyze the collected data. Estimating goodness-of-fit for the suggested research model is the first step in SEM model testing. In this study, the $X^{2} /$ degrees of freedom ratio was estimated as $3.38(857.034 / 224)$. The Comparative Fit Index (CFI) was 0.952, the IFI was 0.952, the TLI was 0.945, and the Root Mean Square Error of Approximation (RMSEA) was 0.069. Given these measures, we can conclude that the model is acceptable. To improve the first model, modification indices were used to identify any theoretically meaningful paths/relationships that are not included in the original model. We found four sets of observed variables having covariance among the same constructs. The second analysis for the revised model was performed (Figure 2), and the revised model was found to fit the data better than the first model: $X^{2}(655.421) / d f(220)$ ratio $=2.98, C F I=0.967$, IFI $=0.967$, $\mathrm{TLI}=0.962$, and RMSEA $=0.057$. 


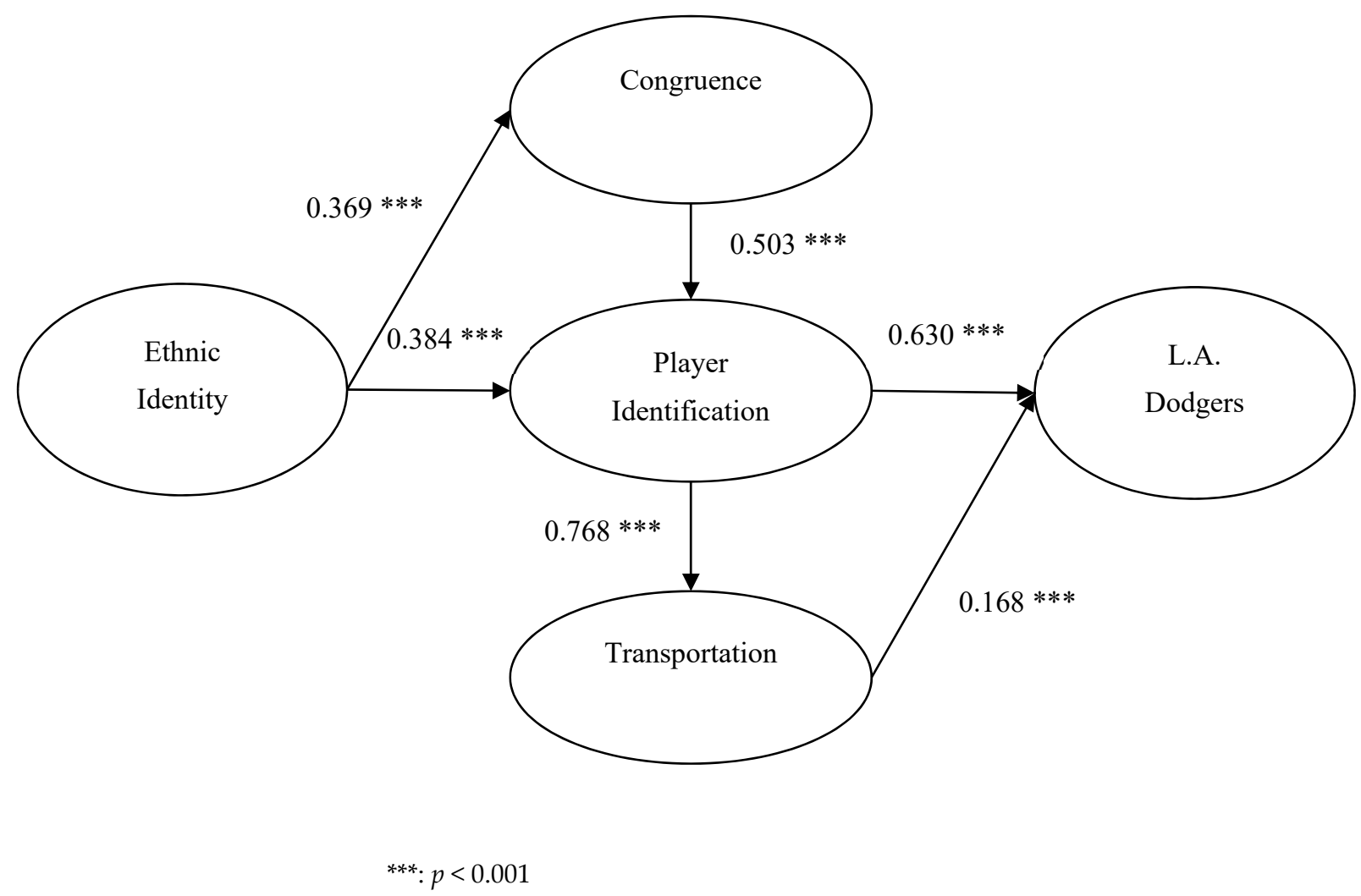

Figure 2. Final model.

The significance of the path weights was examined for all hypothesized constructs, and their associated measures and relationships were significant at the level of $p<0.05$. The final model showed that all six hypotheses were supported. In support of $\mathrm{H}_{1}$, ethnic identity had significant direct effects on player identification $\left(\mathrm{H}_{1}: \alpha=0.384, p<0.001\right)$, and the mediating role of congruence was also found. Ethnic identity influenced congruence $\left(\mathrm{H}_{3 \mathrm{a}}\right.$ : $\alpha=0.369, p<0.001)$, and congruence was linked to player identification $\left(\mathrm{H}_{3 \mathrm{~b}}: \beta=0.503\right.$, $p<0.001$ ). This study found the mediating effects of congruence along with the direct relationship between ethnic identity and player identification. For consequences of player identification, it influenced attitudes toward the L.A. Dodgers $\left(\mathrm{H}_{2}: \beta=0.630, p<0.001\right)$. Transportation was found to be mediating between player identification and attitudes toward L.A. Dodgers. Player identification influenced transportation $\left(\mathrm{H}_{4 \mathrm{a}}: \beta=0.768\right.$, $p<0.001)$, and transportation influenced attitudes toward the L.A. Dodgers $\left(\mathrm{H}_{4 \mathrm{~b}}: \beta=0.168\right.$, $p<0.001)$.

\section{Discussion and Conclusions}

This study investigated the effects of an ethnic player on international audiences of MLB. Using player identification as a major mediating variable, the roles of ethnic identity were explored. The findings of this study showed that ethnic identity influenced player identification (H1). People who hold strong ethnic identity felt more self-identification with the ethnic player. This relationship was mediated by the congruence perception between self and player (H2). Player identification also directly influenced attitudes toward the L.A. Dodgers (H3). It was found that an ethnic player could make international audiences become fans of the team that ethnic players belong to. Transportation was also found to mediate relationships between player identification and attitudes toward the L.A. Dodgers (H4).

This study provides academic implications about the roles of ethnic identity among Asian audiences. Asians have a collectivistic culture and hold strong ethnic identities. Cultural characteristics make them love ethnic players of the same ethnic background. 
Social identity theory explains attachment to in-group sports players, but ethnic identity provides deeper understanding as to how ethnic identity works in audience behaviors of Asians. Korean baseball fans like Ryu mainly because he is Korean; they are happy when Ryu performs well, and they cheer for him when he is in trouble. Most MLB fans may cheer for their favorite teams, but it may not be common for them to love players primarily based on their nationalities or ethnic backgrounds.

This study showed that the hierarchical processing model of sport team loyalty was confirmed. It is found that player identification is a major mediator for the proposed model, and it supported the exiting literature [23]. Team loyalty to the L.A. Dodgers by Korean fans started with ethnic identity. More specifically, ethnic identity influenced player identification, which in turn is related to team loyalty. It means that ethnic identity is a foundation of self-identification to ethnic players [22]. This result showed the unique explanation for Asian identity and the way it works.

Another point is the roles of mediating variables. It is found that self-congruence mediated the relationship between ethnic identity and player identification. Ethnic identity influences congruence, and congruence strengthens the relationship. It is well documented that congruence is important to be persuasive $[27,38]$. This study showed the role of congruence in the identification processes.

The transportation experiences of MLB also mediated the relationship between player identification team attitudes toward the L.A. Dodgers. When people feel immersed in a televised program, they hold more favorable attitudes toward the primary object in the program. It is suggested that identification with a character leads to transportation [46], and transportation is a significant antecedent of attitudes [44]. Both of these propositions were adapted to the sport player as a mediator in this study.

This study provides managerial implications. Sports teams try to recruit potential players to enhance overall team performance, and this study shows that recruiting international players is an effective marketing strategy to broaden global fandom. This is a traditional strategy for international marketing, but Asian audiences can be significant targets of ethnic marketing due to their unique cultural characteristics. MLB could sell broadcasting rights to international markets and make money by selling merchandise of Asian players.

Congruence is important. It means that ethnically typical players are more favored by ethnic consumers. Unlike the United States or many European countries that are known as the melting pot of culture and ethnicity, ethnic diversity in Asian countries is limited due to historical homogeneity. Many countries have comparatively similar ethnic backgrounds and people feel more comfortable and united when they cluster together. These cultural characteristics provide practical implication for international sport marketing.

Transportation is also found to mediate the relationship with team attitudes. Transportation means the positive and immersive experiences. Playful and exciting team management is necessary because fans and audiences want those intimate experiences with the players they root for.

This study has limitations. Only one player is included as a research target, namely, Hyun-jin Ryu. As MLB currently houses a fair number of Korean players, more players need to be considered to overcome this limitation, although none of them have such a high name value close to Ryu as of now. Furthermore, future studies could explore diverse sports players other than baseball to secure generalizability of the findings, such as soccer, American football, and golf. Son Heung-min of the Tottenham Hotspur of The English Premier League (EPL), Younghoe Koo of the Atlanta Falcons of the National Football League (NFL), and Ko Jin-young of the Ladies Professional Golf Association (LPGA) are some of the names to be considered, especially with their international breakthroughs as of late. This study only collected Korean samples for Korean sports players. Future research could also collect samples from various countries to generalize the results of this study. 
Author Contributions: Conceptualization, J.-W.J.; methodology, J.-W.J.; software, J.-W.J. and J.-H.C.; validation, J.-W.J. and J.-H.C.; formal analysis, J.-W.J. and J.-H.C.; investigation, J.-W.J. and J.-H.C.; resources, J.-W.J., J.-H.C. and J.-H.L.; data curation, J.-W.J. and C.J; writing-original draft preparation, J.-W.J. and J.-H.C.; writing-review and editing, J.-H.L.; visualization, J.-W.J., J.-H.C. and J.-H.L.; supervision, J.-W.J.; project administration, J.-W.J. All authors have read and agreed to the published version of the manuscript.

Funding: This research received no external funding.

Institutional Review Board Statement: Approved by Marketing Communication Research Institute at Dankook Univeristy.

Informed Consent Statement: Informed consent was obtained from all subjects involved in the study.

Data Availability Statement: Not available.

Acknowledgments: We would like to thank all the participants of the survey.

Conflicts of Interest: The authors declare no conflict of interest.

\section{References}

1. Go Watch First-Time All-Star Shin-Soo Choo, Who Might Be the Greatest Korean Major Leaguer Ever. Available online: https:/ / www.mlb.com/cut4/shin-soo-choo-might-be-the-greatest-korean-player-ever-c284979626 (accessed on 1 August 2021).

2. Tajfel, H. Experiments in Intergroup Discrimination in a Vacuum, the Context of Social Psychology: A Critical Assessment; Academic Press: London, UK, 1970; pp. 69-119.

3. Cialdini, R.B.; Borden, R.J.; Thorne, A.; Walker, M.; Freeman, S.; Sloan, L.R. Basking in reflected failure: Three (football) field studies. J. Personal. Soc. Psychol. 1976, 39, 406-415. [CrossRef]

4. Snyder, C.R.; Lassengard, M.; Ford, C.E. Distancing after group success and failure: Basking in reflected glory and cutting off reflected failure. J. Personal. Soc. Psychol. 1986, 51, 382-388. [CrossRef]

5. Allport, G.W. The Nature of Prejudice, 25th ed.; Addison-Wesley: Reading, MA, USA, 1954.

6. Walker, L.H.M. Processes of Identity Integration: An Examination of Sports \& Ethnic Identities. Ph.D. Thesis, University of Minnesota, Minneapolis, MN, USA, 2016.

7. Wann, D.L. Understanding the positive social psychological benefits of sport team identification: The team identification-social psychological health model. Group Dyn. Theory Res. Pract. 2006, 10, 272. [CrossRef]

8. Tajfel, H.; Turner, J.C. An integrative theory of intergroup conflict. In The Social Psychology of Intergroup Relations; Austin, W., Worchel, S., Eds.; Brooks/Cole: Monterey, CA, USA, 1979; pp. 33-47.

9. Riggins, S.H. Ethnic Minority Media: An International Perspective; Sage: Newbury Park, CA, USA, 1992.

10. Olmedo, E. Acculturation: A psychometric perspective. Am. Psychol. 1979, 34, 1061-1070. [CrossRef]

11. Tajfel, H. Human Groups and Social Categories; Cambridge University Press: Cambridge, UK, 1981.

12. Phinney, J.S.; DuPont, S.; Espinosa, C.; Revill, J.; Sanders, K. Ethnic identity and American identification among ethnic minority youths. In Journeys into Cross-Cultural Psychology Subtitle: Selected Papers from the Eleventh International Conference of the International Association for Cross-Cultural Psychology; Bouvy, A., van de Vijer, F.J.R., Boski, P., Schmitz, P., Eds.; Swets \& Zeitlinger: Berwyn, PA, USA; pp. 167-183.

13. Worrell, F.C.; Conyers, L.M.; Mpofu, E.; Vandiver, B.J. Multigroup ethnic identity measure scores in a sample of adolescents From Zimbabwe. Identity Int. J. Theory Res. 2006, 6, 33-59. [CrossRef]

14. Schmuck, P.; Kasser, T.; Ryan, R.M. Intrinsic and extrinsic goals: Their structure and relationship to well-being in German and U.S. college students. Soc. Indic. Res. 1999, 50, 225-241. [CrossRef]

15. Kolinsky, E.; van der Will, W. The Cambridge Companion to Modern German Culture; Cambridge University Press: Cambridge, MA, USA, 1998.

16. Lee, J.; Park, T. The Koreans cultural genes and the restauration of community spirit: Focused on the film (The Bacchus Lady). Humanit. Contents 2017, 45, 149-172. [CrossRef]

17. Jun, J.W.; Hong, D. Factors influencing cultural identity of Korean U.S. residents: A focus on media uses, direct experiences, and demography. J. Speech Media Commun. Res. 2017, 16, 287-308.

18. Jun, J.W.; Ham, C.D.; Park, J.H. Exploring the impact of acculturation and ethnic identity on Korean U.S. residents' consumption behaviors of utilitarian versus hedonic products. J. Int. Consum. Mark. 2014, 26, 2-13. [CrossRef]

19. Ware, A.; Kowalski, G.S. Sex identification and the love of sports: BIRGing and CORFing among sports fans. J. Sport Behav. 2012, 35, 223-236.

20. Kelman, J.C. Process of opinion change. Public Opin. Q. 1961, 25, 57-78. [CrossRef]

21. Kim, Y. The relationship between attribute of professional sport yeam, yeam Identification, corporate identification, and corporate image: Focusing on sponsorship identification model. J. Korean Mark. Assoc. 2004, 19, 91-120.

22. Harrolle, M.G.; Trail, G.T. Ethnic identification, acculturation and sports identification of Latinos in the United States. Int. J. Sports Mark. Spons. 2007, 5, 234-253. [CrossRef] 
23. Pons, F.; Laroche, M.; Nyeck, S.; Perreault, S. Role of sporting events as ethnoculture's emblems: Impact of acculturation and ethnic identity of consumers' orientation toward sporting events. Sport Mark. Q. 2001, 10, 31-240.

24. Trail, G.T.; Anderson, D.F.; Fink, J.S. A theoretical model of sport spectator consumption behaviour. Int. J. Sport Manag. 2000, 12, 217-227.

25. Ricard, W.J.; Yam, B.L. Soccer fans' motivations, attitudes, and behavioral intentions across ethnicity and gender lines: Are Hispanics in the United States more passionate about soccer than Caucasians? Public Policy Adm. Rev. 2016, 4, 43-57.

26. Ha, J.P.; Ha, J.H.; Han, K. Online sport consumption motives: Why does an ethnic minority group consume sports in a native and host country through the Internet? Int. J. Sport Manag. Recreat. Tour. 2013, 11, 63-89. [CrossRef]

27. Yi, Y.J.; La, S.A. Brand personality—Brand identification-Brand equity model: An exploratory study on the difference between users vs. non-users. J. Korean Mark. Assoc. 2002, 17, 1-32.

28. Kim, H.; Kim, B. The relations among comsumer need satisfaction, sports star brand attachment and consumer behavior intention in product brand sponsored by sports start brand. Korean J. Sport Manag. 2011, 16, 43-57. [CrossRef]

29. Foster, G.; Greyser, S.A.; Walsh, B. The Business of Sports: Text and Cases on Strategy and Management; Thomson South-Western: Mason, OH, USA, 1996.

30. Robinson, M.J.; Trail, G.T. Relationships among spectator gender, motives, points of attachment, and sport preference. J. Sport Manag. 2005, 19, 58-80. [CrossRef]

31. Pifer, N.D. An Examination of Star Players' Effects on the Branding Process of Professional Sports Teams. Master's Thesis, Marshall University, Huntington, WV, USA, 2012.

32. Schofield, J.A. Performance and attendance at professional team sports. J. Sport Behav. 1983, 6, 196-206.

33. Rifon, N.J.; Choi, S.M.; Trimble, C.S.; Li, H. Congruence effects in sponsorship: The mediating role of sponsor credibility and consumer attributions of sponsor motive. J. Advert. 2004, 33, 29-43. [CrossRef]

34. Kahle, L.R.; Homer, P.M. Physical attractiveness of the celebrity endorser: A social adaptation perspective. J. Consum. Res. 1985, 11, 954-961. [CrossRef]

35. DeSarbo, W.S.; Harshman, R.A. Celebrity brand congruence analysis. J. Curr. Issues Res. Advert. 1985, 8, 17-52.

36. Koo, J.; Lee, Y. Sponsor-event congruence effects: The moderating role of sport involvement and mediating role of sponsor attitudes. Sport Manag. Rev. 2019, 22, 222-234. [CrossRef]

37. Kwon, E.; Ratneshwar, S.; Kim, E. Brand image congruence through sponsorship of sporting events: A reinquiry of Gwinner and Eaton (1999). J. Advert. 2016, 45, 130-138. [CrossRef]

38. Livingstone, S.M. Interpreting a television narrative: How different viewers see a story. J. Commun. 1990, 40, 72-85. [CrossRef]

39. Green, M.C.; Kass, S.; Carrey, J.; Herzig, B.; Feeney, R.; Sabini, J. Transportation across media: Repeated exposure to print and film. Media Psychol. 2008, 11, 512-539. [CrossRef]

40. Tal-Or, N.; Cohen, J. Understanding audience involvement: Conceptualizing and manipulating identification and transportation. Poetics 2010, 38, 402-418. [CrossRef]

41. Green, M.C.; Brock, T.C. The role of transportation in the persuasiveness of public narratives. J. Personal. Soc. Psychol. 2000, 79, 701-721. [CrossRef]

42. McQueen, A.; Kreuter, M.W.; Kalesan, B.; Alcaraz, K.I. Understanding narrative effects: The impact of breast cancer survivor stories on message processing, attitudes, and beliefs among African American women. Health Psychol. 2011, 30, 674-682. [CrossRef]

43. Hwang, Y.; Jeong, S. Persuasive effects of branded entertainment: Focusing on the effects of ad movies. Korean J. Advert. 2014, 25, 83-104. [CrossRef]

44. Murphy, S.T.; Frank, L.B.; Chatterjee, J.S.; Baezconde-Garbanati , L. Narrative versus nonnarrative: The role of identification, transportation and emotion in reducing health disparities. J. Commun. 2013, 63, 116-137. [CrossRef] [PubMed]

45. Moyer-Gusé, E.; Chung, A.H.; Jain, P. Identification with characters and discussion of taboo topics after exposure to an entertainment narrative about sexual health. J. Commun. 2011, 61, 387-406. [CrossRef]

46. Green, M.C.; Brock, T.C.; Kaufman, G.F. Understanding media enjoyment: The role of transportation into narrative worlds. Commun. Theory 2004, 14, 311-327. [CrossRef]

47. Busselle, R.W.; Bilandzic, H. Fictionality and perceived realism in experiencing stories: A model of narrative comprehension and engagement. Commun. Theory 2008, 18, 255-280. [CrossRef]

48. Gwinner, K. A model of image creation and image transfer in event sponsorship. Int. Mark. Rev. 1997, 14, 145-158. [CrossRef]

49. Mael, F.; Ashforth, B.E. Alumni and their alma mater: A partial test of the reformulated model of organizational identification. J. Organ. Behav. 1992, 13, 103-123. [CrossRef]

50. Holbrook, M.B.; Batra, R. Assessing the role of emotions as mediators of consumer responses to advertising. J. Consum. Res. 1987, 14, 404-420. [CrossRef] 